\title{
CONFLICTS AND THE ECONOMY OF ESTEEM
}

\author{
Conflictos y la economía de la estima
}

\author{
CHRISTIAN LAZZERI
}

Universidad de Paris X Nanterre

\begin{abstract}
RESUMEN
Partiendo de trabajos recientes sobre la economía de la estima social, este ensayo investiga las maneras a través de las cuales la estima social se demanda y se distribuye. Empezando desde una situación en la cual la estima es distribuida de manera desigual según la posición social de las personas, el ensayo explica cómo esta distribución desigual de reconocimiento genera conflicto social. Los conflictos por el reconocimiento pueden ser interpretados como algo peligroso para la preservación de las relaciones sociales porque no parecen dejar lugar a compromisos y más bien radicalizan las identidades políticas. Este ensayo somete este tipo de interpretación a crítica y provee una manera de pensar los conflictos por el reconocimiento como constitutivos para la integración social.
\end{abstract}

Palabras clave: Estima, respeto, reconocimiento, dominación, conflicto, economía, integración social.

\begin{abstract}
Starting from recent works devoted to the economy of esteem, this paper investigates the way in which esteem is demanded and distributed. Starting from the situation of its inequality of distribution related to the various types of social positions, it asks how this difference of attribution of recognition generates conflicts. Struggles for recognition can be interpreted as dangerous conflicts for the preservation of social relations because of the fact that they do not seem to admit the possibility of compromises and create situations characterized by the logic of "either/or" specific to identity politics. The paper submits this thesis to criticism, and provides a way to think about such struggles for recognition as constitutive of social integration.
\end{abstract}

Key words: Esteem, respect, recognition, domination, conflict, economy, social integration.

The title of this article refers to the project of an economy of esteem stemming from the work of economists and philosophers like Ph. Pettit, G. Brennan, C. Tyler and D. M. Levy. These authors seek to extend the problems and concepts of economic analysis to esteem understood as a particular good which is demanded and offered like a material good, but adheres to a different logic. It is usually asserted that there are two ways to guide individuals towards a common good: either the market, i.e. the "invisible hand", or the state, i.e. the "iron hand".

The state is often defined as an "iron hand" because of its capacity to distribute legally codified rewards or sanctions in order to correct individual and collective behaviour. This dichotomy between market and state generates a schema which aims to transfer state 
functions to the market when the former is no longer in a position to assume them or to transfer market functions to the state when the former cannot succeed in coordinating collective actions. However, according to Brennan and Pettit (2004), such a dichotomy is inaccurate because there is another way of regulating behaviour which does not involve the invisible or the iron hands of the market and the state. This alternative means of regulation is referred to as the "intangible hand". The "intangible hand" belongs neither to the market nor to the state, but to the non-commercial behaviour of civil society. In a sense, it looks like the invisible hand because it also produces non-intentional sanctions but it differs from the invisible hand because it does not produce actions which generate effects on others. Instead, the intangible hand is limited to interactions between actions (performances) and attitudes (distribution of esteem). These interactions are based on the conformity of agents' actions to collective standards, making it possible to shape people's behaviour and orientate it in a direction which appears socially advantageous when collective esteem is distributed among cooperative behaviours. One might rightfully wonder if the connection made by Brennan and Pettit, between the logic of the invisible hand and that of the intangible hand, does not obscure the fact that the actions of the state cannot be reduced to the workings of an iron hand. This is because the state constantly interferes in the social logic of the distribution of esteem, redistributing esteem for the purpose of governance and by means of suitable devices which have been theorized since at least the $17^{\text {th }}$ century. In any case, one can only meaningfully engage in a discussion about the role of the state in the economy of esteem after its principles and some of its consequences have been studied (Ihl, 2004, Elias, 1974). The aim of this paper is not to follow step by step the development of the conceptual framework of the economy of esteem or to evaluate the relevance of "theorems" on the supply and demand of esteem proposed by Brennan and Pettit. Rather, it is to analyze the way in which esteem is allocated within the context of social cooperation and social conflict in order to think about the connections between these two kinds of action.

According to most contemporary theorists of justice, social conflicts are first and foremost causes of social disorder because they threaten to break-up social relationships. From the viewpoint of normative theories of justice, conflicts are justified only in situations where basic social structures and their constitutional expressions are threatened by obvious violations of basic rights. In general, these theories seek to substitute social cooperation -normatively defined by principles of justice- for social conflicts, in order to demonstrate the fundamentally pacifying aspects of these principles. On the other hand, many social scientists admit that conflicts exist and that they constitute an irreducible dimension of social life. A number of these scientists, however, do not abandon normative considerations when thinking about social conflicts, leading them to maintain a distinction between conflicts that are socially acceptable and those that are not. In the following pages, I shall discuss the genesis of social conflicts from the point of view of an economy of esteem. I shall also consider the question of how social conflicts affect social relationships by considering whether it is appropriate to reduce their occurrence to the breakdown of cooperative relations or whether, on the contrary, under certain conditions, social conflicts constitute an important form of social integration. 
The project of an economy of esteem begins with the statement of the fundamental properties of esteem and its distribution. Esteem, as Brennan and Pettit define it in their pioneering work, comprises a great number of specific properties. In what follows I shall examine only those properties that are interesting in regards to the relationship between cooperation and conflict.

\section{SUPPLY AND DEMAND OF ESTEEM}

The first property of esteem consists of its attractiveness, which can be expressed in two ways. The first reason to desire esteem lies in its instrumental character. To obtain esteem for the achievement of a particular performance or for the possession of a particular ability furthers, in a general way, cooperation with others insofar as public knowledge of distributed esteem produces the effect of reputation. Reputation works as a kind of anonymous guarantee concerning the value of the performances or capacities of a social group or an individual. Reputation makes it possible to know a priori if these performances or capacities correspond to the expectations of those who engage in contact or transactions with those groups or individuals. If one's performances or capacities correspond to expectations, then the cycle of reputation can grow by way of an "informational cascade" ( see below) and the supply of esteem will increase according to a quantitative extension which builds on the satisfaction of the seeker (Brennan and Pettit, 2004: 146), thus facilitating his possibilities of cooperation.

Besides these instrumental reasons, which transform esteem into a primary good in accordance with Rawls' considerations, esteem can also be valued as a good in and of itself. Beyond its instrumental value, esteem possesses intrinsic value. In other words, regardless of how useful esteem is for cooperation, esteem generates a sense of satisfaction within the self. Although Brennan and Pettit do not go far in this regard since it does not concern their area of study, the economy of esteem is a process which matters to the constitution of both a collective and an individual identity.

Once esteem is understood, either in an instrumental way or in terms of its intrinsic good, it can be examined using two types of rather heterogeneous criteria which necessarily vary with the social group considered. The first involves the evaluation of how performances and capacities are socially useful, i.e. how they contribute to the reproduction of collective interests, regardless of their content. The other criterion involves the aesthetical evaluation of the performance itself. Even if its results are not of particular interest to society, the performance may nevertheless reveal a given structure of action in which the pairing of its means and ends manifests some quality of economy, neatness, power, etc. that is particularly appreciated (Brennan and Pettit, 2004: 103). These two criteria undoubtedly apply to a great number of performances in a great variety of fields, including the arenas of economic, athletic, intellectual, ethical, and civic performance. Although Brennan and Pettit do not mention it, religious and cultural practices could also be praised in terms of the economy of esteem, at least with regard to their contribution to social reproduction. 
A second property of esteem is that, even though it is an object of offer and demand and even though it satisfies the interests of its recipient, esteem cannot be the subject of a business transaction between agents because this would, in principle, destroy it. Pursuing and acquiring esteem cannot take the form of an economic interaction because any agent $\mathrm{Y}$ who exchanges goods with agent $\mathrm{X}$ is interchangeable insofar as he is viewed only as the owner of resources able to satisfy a utility.

If the esteem offered by $X$ belonged to an economic relationship, it would only be grounded in X's need and not in Y's performance, which would necessarily frustrate $Y^{\prime}$ s desire for esteem. On the other hand, a performance can be esteemed to the degree that it satisfies a social need in a broad sense, while simultaneously bringing psychological satisfaction through a particular use of the capacities it reveals. It is thus possible that a given performance may not satisfy the needs of the economic agent who observes it, but it is nevertheless esteemed, thereby satisfying the agent without being particularly good. However, beyond these strictly economic relationships, agents can enter in a utility exchange of signs of esteem expressed in relationships of civility, as theorized in the 17th and 18th centuries by authors like Pierre Nicole or Bernard Mandeville. One could then maintain that, just as the satisfaction of material utility constitutes the explicit goal of the business trade, in the same way, satisfaction of the desire of esteem constitutes the explicit goal of the exchange of signs of esteem. This idea of the exchange of signs of esteem, however, faces a difficulty similar to that of the preceding idea: one cannot intentionally distribute esteem for the sole purpose of receiving some in return. In cases where reciprocal esteem would be granted in the form of a "barter", $X$ would esteem the capacities of $Y$ only insofar as they were justified by the satisfaction $X$ experiences upon receiving esteem from $Y$ in return. This means that if $X$ was not esteemed by $Y$, then his or her own esteem of $Y$ would not take place irrespective of the value of Y's capacities. This type of exchange is doomed to failure since both partners are aware of the fact that it is impossible for them to obtain what they seek. They indeed ask for a distribution of esteem which corresponds to their capacities and performances, an esteem which leads primarily to a form of positive relationship with one self. If the distribution of esteem could be equivalent to a utility relationship, the value of the performances and capacities of the partner who enjoys them would inevitably be rejected since the esteem he or she obtains would only pay that which he or she initially granted to the other. The granting of esteem in a purely utilitarian way, in which reciprocity exists depending on the need or the satisfaction expressed by each partner, will not actually satisfy either of them. In short, to be gratifying, the distribution of esteem must be credible and must be based on specific performances which can be evaluated. Otherwise, it will be associated with a mechanism of self-deception that affects both partners of the exchange in such a way that neither of them will be satisfied by the "pay-off" they obtain (Lazzeri, 2007c).

This failure of utility reciprocity allows us to draw two conclusions. First, that the distribution of esteem must have an impersonal character: $X$ does not distribute esteem to $\mathrm{Y}$ because he or she benefited beforehand from $\mathrm{Y}$, but only because of the particular performance of $Y$. However, this impersonal evaluation of the performance is possible only when there are socially constructed standards that one can confront and that constitute 
various kinds of measurements, sometimes vague and sometimes precise, depending on the nature of the action and its standard of reference, as Smith foresaw in his Theory of Moral Sentiments (Smith, 1999: 176 ff.). Such standards exist and are as varied as the whole of social practices. In a general way, the distribution of esteem and contempt depends on the way in which the observers and the actors perceive the performances. If the effects of the actor's behaviour are derived from his desire for esteem, the actor must have certain knowledge of what the observers think of various performances. The actor must have an idea of the standards or normative ideals by which the observers will evaluate his or her performance (Brennan and Pettit, 2004: $67 \mathrm{ff}$; Mead, 2006: 154-155). These standards of evaluation are built from average performances which are used as collective references in order to make comparisons among the actors by locating them above, below or equal to reference standards.

The second consequence is that esteem cannot be given; it can only be distributed. If esteem is indeed an evaluative attitude, then it will rest on a performance. If, on the contrary, esteem were a gift, it would be free, i.e. it could be granted without any performance. ${ }^{1}$ Since esteem is an evaluative attitude, it escapes the logic of the gift. Esteem as an evaluative attitude is an object of common knowledge: no one believes that it can be given freely or that it can be exchanged for purposes of utility, as we saw above. Thus, esteem can only be distributed involuntarily-not arbitrarily and not for free.

The third property of esteem is that it is a scarce good, since the attention which can be devoted to performances cannot be distributed among each one of them (Brennan and Pettit, 2004: 21). Attention will thus tend to be selective, i.e. distributed among the performances which, while presenting a contribution to the social utility or satisfying aesthetic criteria, exceed the standards of reference. The actors then tend to become competitors who wish to increase their benefit of esteem by drawing attention to themselves and by presenting notable performances with respect to existing standards (see also Honneth, 2000: 154155).

Distributors of esteem can also benefit from this capacity of distribution. In other words, the competition also affects the position of the distributor. Accordingly, esteem will be required and, distributed by way of comparison (Brennan and Pettit, 2004: 21). Esteem for the various performances will be awarded if the actor's capacity exceeds the standards which define average performances. While below average performances will attract only contempt, average performances will attract neither high nor low esteem. This comparison not only affects individuals in relation to given social standards, but also in connection with the performances of their reference group and the standards they adopt. If a given group succeeds in giving very high performances, the individuals who belong to that group will

1 See Brennan and Pettit, 2004: 52-53. In order to avoid any ambiguity in their approach, it is necessary to understand that their recourse to the concept of gift refers only to a situation in which esteem would be dispensed without corresponding performance (whence the concept of "gratuitousness"), which does not mean without interested intention, since it is a question of obtaining esteem in return, which can be a way of denying gratuitousness. 
not benefit from an attitude of esteem. If, on the contrary, performances of a given group are relatively weak, individual performances will be perceived to be good.

The fourth property of esteem is that its demand, in a general way, cannot be an "active", or formulated in a direct way to the distributors of esteem. Direct and open requests for esteem can only be made insofar as one exerts control over the factors which ensure esteem. However, the attempt to exert this control may become as counter-productive as Elster's "paradox" related to spontaneous behaviour. According to this paradox, rational control of the conditions of spontaneity cancels, by definition, the spontaneity itself and its benefits (Elster, 1986: 47 ff). The same applies to esteem: an open request for esteem can prove to be counter-productive since pursuing esteem will not be considered "good" behaviour by the distributors of esteem. One will thus not inevitably obtain esteem by wanting it consciously and rationally and openly showing this desire to distributors. One could add that when the request for esteem is carried out in a direct and open way, superimposing itself onto the performance or onto the possession of the capacity, it is likely not to be satisfied because it is too visible and too insistent, thus restricting the judgment of the distributors. After all, it is generally not considered acceptable to be almost constrained by the desire for a partner.

In short, in order for social requests to be satisfied, it is better for them not to be visible. The point remains, however, that the active and open request for esteem is not the only possible way to receive esteem: there are also "virtual" requests where the desire for esteem is not visible, but the actor still plays a decisive part in the request. It is also entirely possible for agents to engage in behaviour that can be esteemed, and, therefore, obtain esteem even if this was not their original purpose. Still, when esteem is obtained, it may satisfy the agent and generate the emergence of a desire for esteem related to the previous action. However, if we assume that other desires may interfere and redirect the agent towards a contrary behaviour, then the desire for esteem may bring the agent back towards his or her first motivation, i.e. obtaining esteem through the implementation of his or her capacities and performances. In this case, we would not be dealing with an open desire, but rather with a desire that would exert a kind of virtual control on behaviour. The pursuit of esteem can, therefore, exist like a disposition or a "second nature", acting unconsciously to redirect individual behaviour so that the agent need not demonstrate, in a counter-productive way, a motivation which may or may not clearly appear to him. One can then obtain the following functional diagram: a D1 desire for esteem and a C1 behaviour, determined by D1, through which one obtains esteem. In other words, C1 satisfies D1. However, if several desires interfere and modify the $\mathrm{C} 1$ behaviour by frustrating the $\mathrm{D} 1$ desire, this can become reactive and can "re-motivate" the agent, bringing him or her back to C1. D1 then resumes control of the agent's behaviour. One can say that, in this case, D1 virtually controls $\mathrm{C} 1$. It thus induces a relatively strong behaviour regarding the desires liable to disturb $\mathrm{C} 1$ when it satisfies D1. In fact, one is here dealing with a motivation similar to that of the desire to follow the principles of justice in Rawls' theory, a motivation which implies a return to stability when one is disturbed by non-cooperative desires. Such is the effect of the virtual request for esteem which plays a kind of "silent" but important part in an agent's behaviour concerning requests for esteem. This one is, as we see, equivalent to 
a production of "states that are essentially by-product" as defined by Elster. ${ }^{2}$ One could then maintain that the seekers' behaviour is a kind of "sens pratique" (practical sense), as described by Bourdieu, where one deals with reasonable and evaluative behaviour. In this instance, the dispositions of agents fit with their opportunities to act and determine what is necessary to do or not to do according to the tacit agreements that rule action without consciously calculating their options (Bourdieu, 1980: 92-103). Admitting such a possibility, one can assert that virtual requests for esteem constitute a better option than open requests. In short, there exist two ways to request esteem: one that is expressed in a direct way, where the seeker's intention appears rather clearly, and another that is expressed through virtual requests, where the request itself does not appear in the foreground.

The fifth property of esteem is as follows: beyond the distribution of esteem, it is possible that distributors dispense what Brennan and Pettit refer to as "esteem-services". "Esteem services" are defined as voluntary acts through which one can increase the probability that the amount of esteem $X$ enjoys will increase due to the fact that these "services" are dispensed by $Y$ and that, in this way, Z's esteem is distributed to $X$, thereby increasing the amount of esteem $X$ already has (Brennan and Pettit, 2004: 57). The first possible service of esteem that can be distributed is paying attention to the performances of $X$ which deserve esteem rather than those which do not attract it. While enjoying esteem is the result of an involuntary distribution of evaluation concerning performances, the attention one pays to these performances is voluntary. By deciding to pay attention rather than to ignore, one opens the door for the distribution of esteem. In other words, one foresees that a possible practice for obtaining esteem consists not only of carrying out valid performances, but of drawing distributors' attention to the performances so that they can be evaluated.

The second possible esteem-service consists of adding to the distributor's attention a public expression of the value of X's performances. One can deal, for example, with X's performance known by each individual within a given group without all the others knowing the performance. The fact that an individual expresses a public judgement of esteem shows others that some view $X^{\prime}$ 's performances favourably. Therefore, if others publicly express their judgment, esteem for $X^{\prime}$ 's performances will become public. In other words, everyone will know that others are estimating X's performances. This would not change anything when the group that distributes esteem is only the sum of the evaluative judgements of each member. However, this would change a lot when many of the individuals who make up this group only dispense esteem publicly for those performances that others have praised publicly because their attention is drawn only to capacities and performances of determined value. Here, one is dealing with the very real creation of public esteem by the mechanism of reputation, which rests on the public judgements of those who tend to make their esteem known to others. Esteem that arises from reputation is relatively resistant and difficult to alter, which explains why reputations are so slow to be broken up despite behaviours that contradict them (ibid. 146, ff.). The third esteem-service consists of

2 A state that is essentially by-product is a state which cannot be obtained by will and in a calculated way. It is a state which can be reached only by one who directly seems to give up reaching it without wanting to make this renunciation a conscious mobile of action, see Elster, 1986: 33, and 1990: 50. 
associating $X$ with oneself so that he may enjoy a particular status. As a result, this status of esteem is divided by $X$, who is capable of similar performances, but has not profited from similar attention.

Now that we have defined attention, testimony and association, let us turn to their consequences. One such consequence seems to be that agents will create voluntary associations only insofar as they can obtain esteem from their associates and from those who are not members of these associations. This esteem comes from being grouped with those who have achieved favourable status and thus have already garnered esteem (ibid, 96). However, it is clear that if voluntary association leads to attention (of the members for one another) and to testimony (of the members with regard to one another), this does not mean that esteem is the only factor that explains voluntary associations. These can be fashioned with other ends in mind, but they nevertheless involve the production of esteem.

These three types of esteem-services (attention, testimony, association) can easily be voluntary, although the attribution of esteem cannot be because it entails a kind of constraint of attribution. In this sense, an esteem-service likens itself to an attitude, even a directed attitude, since it will exert influence over the behaviour of those who seek to obtain this service, which can be granted or refused. Thus it is possible, for example, when a request for esteem is exposed directly and openly (rather than being formulated virtually), not to give attention to the performance in order to avoid being constrained to evaluate it positively because one does not wish to do so for the reasons clarified above (4th property).

Insofar as the esteem-service is the result of the decision of the distributor, there can be multiple motivations behind a refusal to pay attention- from a distributor's refusal to sanction the transgression of the virtual request for esteem to the refusal of two competitors to pay attention to one another's performance because they want to reserve more esteem for their own performances. Among these motivations, one often finds those which depend on the agents' membership in what are called "involuntary associations". One can define membership in these groups in the following way: it occurs when agents who fall into a particular category, such as sex, race, language, ethnic origin, or a social status that is extremely difficult to give up, are met with contempt because of their respective bonds of membership. The chief characteristic of involuntary associations is that its members do not ask to belong to it, cannot escape from it and, as a result of membership, are subjected to attitudes of social contempt (Brennan and Pettit, 2004: 225, 315). In such situations, even when agents appear capable of performances higher than the standards of reference, because of their previous membership to discriminated groups, they risk being almost systematically deprived of esteem-services which would make it possible to evaluate these same capacities or performances. In short, this directing attitude on the part of the esteem-service suggests an asymmetrical relationship between individuals or between social groups, making it appear as though one dominates the other. One can conclude this analysis of the properties of esteem with a general remark: the comparative character of esteem, the variability in its distribution, and its possession of some instrumental character, according to Brennan and Petit, differentiates esteem from recognition. This distinction 
is accepted by the majority of contemporary philosophers interested in the theory of recognition, like Habermas, Rawls, Honneth, Walzer, Fraser, Margalit and others who speak of the difference between respect and esteem, and between their respective effects: self-respect and self-esteem. In general, one can say that respect refers to the valuing of properties or qualities whose possession integrates the individuals into the political community: it corresponds to the moral powers of the rational and the reasonable in Rawls (Rawls, 1986); to the capacity for mutual understanding grounded in argumentation in Habermas (1986); to the deliberative capacities in Thomson and Gutmann (1996) and in Dryzek (2000); to the aptitude for autonomy in Honneth (2000, 2003), Margalit (1996) and Keshen (1996); and to the aptitude for equal participation defended by Fraser (2005). In short, these properties are equally possessed by individuals and thus make them "socially visible" as full partners of cooperation or interlocutors in the deliberative processes used to settle disagreements. For Brennan and Pettit, as for the previous authors, recognitionrespect sanctions only invariant and equal agents' capacities which confer them universal and invariant dimensions. According to Pettit, this recognition refers to their deliberative capacities to solve disagreements concerning common interests (1997: 56; 2001: 79). Thus recognition, according to Brennan and Pettit, presupposes neither classification, nor competition, nor comparison with the characteristics or the standard performances of a specific group. One may, however, wonder whether attention, being a scarce good, is not also likely to be distributed in a selective way as it is in the cases of recognition and esteem. This feature would then tend to bring respect and esteem closer to one another. In reality, this is not the case because the distribution of esteem always puts the classification of others in a comparative and competitive situation, whereas recognition aims only at equality among agents: it thus constitutes, according to Brennan and Pettit, a "moral" attitude which simply involves the observation of performances. ${ }^{3}$

For Brennan and Pettit, this difference between the effect of recognition and the effect of esteem refers to a principle of priority for dispensing recognition over esteem. One can obtain esteem or contempt because of one's performances but, in both cases, this is based on the status of the agent, which conditions any possible evaluation. The agent is initially the subject of recognition which renders him or her "socially visible" as a person and, subsequently, makes possible the operation of dispensing (or not dispensing) esteem. The kind of recognition which makes agents visible constitutes a more fundamental request insofar as it constitutes the condition of its distribution. Having admitted this point, it is possible to supplement Brennan and Pettit's thesis concerning two important points.

The first is that it is perfectly possible to view recognition as a social function for the distribution of positive evaluations regarding universal competences. There is no objection attached to this point: Brennan and Pettit are justified when they consider that one is here dealing with a true form of recognition. On the other hand, there is, strictly speaking, nothing in their thesis which authorizes them to maintain such a restricted conception of

\footnotetext{
"Recognition simply involves the presumption that the other, whoever she may be, is a moral equal. This is a matter of an attitude and not action, and we do not think that scarcity applies in this domain", Brennan and Pettit, 2004: 189 ff. See also Honneth, “Recognition as ideology" (Honneth, 2007).
} 
recognition and to exclude esteem from this field. It is possible that recognition through discursive integration obtained by deliberation seekers (i.e., the desire to be simply recognized as interlocutors) be accompanied, despite everything, by a certain "invisibility" of their performances in the absence of or by a refusal to distribute esteem-services (like simple attention to performances). In other words, if the distribution of esteem presupposes the existence of a preliminary recognition, the existence of the latter by no means implies that self-esteem services will be obtained or that an agent will gain the satisfaction of being estimated. Under these conditions, the invisibility of performances and the capacities of the seekers can affect an important aspect of their identity in a way that it is not compensated for by their simple recognition as interlocutors. In short, there is not only one way to become socially invisible. One can conclude from this that if there are struggles for recognition, they must include "recognition-respect" as well as "recognitionesteem", even if it is possible to distinguish their modalities, at the very least, by way of their specific objects.

The second point is that just as there is an "esteem-service" which consists of paying attention to capacities or to socially variable agents' performances in order to testify to their value or to associate themselves with one's own performances (see above), in the same way there must also exist a respect-service which consists of paying attention to the capacities and performances of universal and invariant agents. One can then agree to call "recognition-service" the general property of the attention lent to capacities concerned with recognition-esteem which also involve recognition-respect. Returning to the priority of recognition over esteem defined by Brennan and Pettit, it follows that there are two fundamental conditions to obtaining any given distribution of esteem: the first is to obtain a recognition-respect service which makes the agent socially visible in his or her fundamental capacities; the second is that once that occurs, the agent must enjoy an esteemservice so that his or her capacities and performances become visible and are rewarded by recognition-esteem. Now that we have determined the definitions and the modalities of demand and offer of recognition, we can analyze the status of conflicts.

\section{TWO CATEGORIES OF CONFLICT?}

One can start from an empirical observation that there exist several kinds of social conflicts, each having specific objects and resorting to autonomous logics whose consequences on social relations are also very different. In order to try to clarify the nature of the conflicts of recognition and at least one of their important effects, one can draw on the analysis of conflicts proposed by Albert Hirschman. In his article "Social Conflicts as Pillars of the Democratic Market Society" (1995), Hirschman, continuing the work of Simmel (1992) and Coser (1982), proposes to distinguish between two categories of conflicts: the conflicts which he calls "divisible conflicts" and those which he calls "indivisible conflicts" (Hirschman, ibid. 357).

In a democratic market society, Hirschman maintains that divisible conflicts are characterized by claims of distribution or redistribution, i.e. material claims which can be more or less 
satisfied in the sense that when distribution and redistribution are open to quantitative variations, they express a capacity for compromise between the sides in conflict. Divisible conflicts are conflicts based on the fact that the interests expressed by each party are quantifiable interests. In these cases, the cursor can move in one direction or the other, until a point of equilibrium is reached that is considered satisfactory by the negotiators. Divisible conflicts are thus par excellence conflicts in which the possibility of negotiation appears. In short, according to Hirschman, and (he believes) unlike the theses defended by Marxists, economic conflicts are integrating conflicts in the sense that their results, i.e. compromises, constitute, to some extent, a tacit pact of tolerance which recognizes and takes into account the existence of the other side's interests. Lastly, divisible conflicts are characterized by their capacity to resurface. Since these conflicts and negotiations reproduce according to the temporal variation of the allowance of resources, they are not, in principle, final conflicts.

Indivisible conflicts, on the contrary, are conflicts based on a principle of exclusion and are expressed not in the form of "more or less", but in the form of "either/or". They are conflicts in which the possibility of compromise gives way to the logic of exclusion which leads to one party dominating the other. This is particularly the case, according to Hirschman, with religious, ethnic or linguistic conflicts: i.e. conflicts which can drift towards a radical dimension and lead to the elimination of one of the opposing parties or with the elimination of (prohibition of religious worship, prohibition to speak such or such language or to promote such or such culture) components of its identity. In these conflicts, where the essential question is that of identity, the role of negotiation is practically excluded because what is proposed by the antagonists is the attempt to find guarantees that an identity can (or cannot) be socially constituted and expressed. One can say that while divisible conflicts seem to be integrating conflicts, indivisible conflicts seem to be conflicts which "dissolve" social relationships.

To summarize Hirschman's position, one could say that conflicts for goods make it possible to renew a version of the "soft trade" analyzed in The Passions and the Interests (Hirschman, 1981, 1984). But, instead of speaking of "soft trade", one should be speaking of the "soft conflicts" related to "soft trade". Conflicts related to scarcity are socially preferable because they are less expensive in terms of social division. By contrast, symbolic conflicts are much more difficult to resolve. Their radicality is related to the logic of "either/or" which is likely to create long-lasting social divisions. In short, whereas distribution conflicts are on the side of interests, symbolic conflicts are on the side of passions. In this account, one would have to conclude that conflicts of recognition constitute conflicts which are dangerous to the preservation of social relationships.

Hirschman's thesis in favour of the unilateral improvement of the social utility of economic conflicts can be criticized, at least with regard to the way in which it interprets conflicts of recognition. One could respond to his analysis by citing the thesis developed by Simmel in his Sociology of Conflict (1992). Simmel maintains that, in general, conflicts occur when social relationships become intolerable. One possible solution, then, consists simply in breaking up the relationship. However, insofar as one chooses to respond to such an intolerable 
situation through conflict, Hirschman reaffirms, in a sense, a social bond with others because conflict constitutes a way of transforming the social relationships they maintain. According to Simmel, conflict does not break up social bonds but, on the contrary, is a way to avoid breaking them up when, prior to the conflict, one would have been tempted to do just that. In other words, it is precisely because one responds to a bad social relationship by conflict that one ends up, in a way, maintaining the social relationship. In this account, conflicts constitute a way to relate to the other which pursues the aim of transforming the social relationship with the other. To summarize Simmel's argument, "what [...] appears as de-socialization is thus in truth only one of the elementary forms of socialization". For Simmel, all types of conflicts constitute a factor of socialization and, on the backdrop of dissension, produce social unity. There is thus no need to make, as Hirschman does, a categorical distinction between types of conflicts. ${ }^{4}$

At first glance, Simmel's thesis seems interesting. However, one could assert that it makes sense only if one considers the fact of conflict and not its stakes or its result. This thesis is acceptable insofar as we consider that, as long as the antagonists of the conflict try to win by mutually increasing the cost of the damage they cause to one another, they indeed remain in a relationship, albeit a conflicting one. However, it is difficult to call this "socialization" for it cannot be avoided that each party's interests can only be satisfied by the elimination of the other party. It is thus necessary to rethink these conflicts of socialization. This can be achieved by understanding this specific category of conflicts as conflicts of recognition, thereby, refuting Hirschman's thesis. From this point of view, the economy of esteem even if it does not constitute the only possible approach - contributes, if one modifies some of its analyses, to making intelligible the concept of the struggle for recognition. For this purpose, one can start with two asymmetrical situations in terms of the request for recognition: a situation of success and a situation of failure. Let us begin with the first.

Insofar as there is a multiplicity of agents who wish to obtain an esteem-service for their performances, it is rational for them to use a strategy of publicity to draw attention to their performances. In addition, one may note that the existence of even a restricted public viewing has an impact on those performances because the competitors know that they are being observed. The observation or, more exactly, the publicity effect related to the observation has an impact on the performance in the form of an incentive to improve it. If the agents manage to obtain an esteem-service and their performances are praised, they will continue to use publicity as a strategy because it will allow them more chances to be observed and evaluated, causing the number of observers to increase and, in turn, increasing the incentive to improve their performances. By widening the circle of distributors to intensify the esteem obtained, they can even, indirectly, set in motion the phenomenon of a widened reproduction of the distribution of esteem. Here, one is dealing with the effect of an "informational cascade" which can be described as follows: when a great number of agents share a particular belief, namely, that $X$ is worthy of esteem, this fact tends to strike a part of the community so that other members, based on this testimony, adopt

4 It is because Hirschman restricted the Simmel's thesis of the conflict as a mean of socialization that we could oppose Simmel's thesis to Hirschman's. 
this belief with regard to $X$. As more agents swell the ranks of the believers, the more this particular belief strikes the community, thereby attracting new believers. This cascade can develop to the point where virtually everyone comes to share this common belief. This can function even if the observers, or those who become or will become believers, do not possess a particular ability to evaluate the merit or the esteem of the subject of this informational cascade. It is even possible, in this diagram, that X, the subject of esteem, does not have the competences which merit this esteem because the distributors make their judgments based on the belief that other distributors believe $\mathrm{X}$ is worthy of esteem. It then becomes difficult to know who has truly observed the performances in question, yet the mechanism of cascade based on belief continues to work. Under these conditions, it is clear that indirect observation and common belief add considerably to the level of esteem which X can enjoy, going so far as to give X a "capital of esteem" relatively difficult to dissipate. However, for the beneficiary of esteem, it does not matter whether esteem is allotted to him or her on the basis of performances that have actually been observed or on the basis of common belief relating to others' observations: esteem remains the same and the reputation the agent obtains considerably increases his or her incentive to improve his or her performances up to the point where he or she cannot improve them any more (Brennan and Pettit, 2004: 148).

But next to these successful situations, there exist an infinite number of less favourable ones, such as those in which strategies of publicity are ineffective. This is particularly the case (see above) with those agents who cannot profit from esteem-services for their performances because of their membership in involuntary associations. What is at stake here are not the agent's capacities or performances, but rather the fact that their identities make them appear -in the eyes of certain agents or social groups- as if they could not have these abilities or capacities in the first place. Standard examples are the a priori failures which result from various forms of social and professional discrimination, where the agents' capacities and competences are recognized through specific, publicly sanctioned indicators (diplomas, abilities, experience), but then are questioned on the basis of characteristics such as sex, ethnic or racial membership, all of which have nothing to do with the exercise of these competences. This type of social contempt, grounded on the decision to ignore an agent's performances, weakens the confirmation of self-esteem because of the agent's inability to comprehend his or her own status and because of the arbitrary character of this ignorance. The recognition such agents require is denied and this appears as an unjustified exclusion which prevents them from entering a community that they have a justifiable claim to enter. Moreover, this phenomenon is long lasting because it deals with the same logic at work in "aggregation of beliefs" cases. In these cases, which involve the effects of esteem capital, we risk negatively strengthening the absence of esteem capital by creating a kind of blindness to the value of individual performances by socially invisible agents (Brennan and Pettit, 2004: 315).

In such situations, explain Brennan and Pettit, agents will tend to implement different behaviours which are not always easy to anticipate because of the complexity of the social conditions involved: one may thus deal with behaviours of disengagement regarding any performance in any field because it seems impossible to escape contempt. This is 
also the case when performances are too weak. This may be accompanied by a search for justification based on the strategy of "sour grapes" described by Elster (1983: 110): the agents may systematically depreciate the various activities and the various fields of distribution of esteem from which they are excluded so as not to have to transfer the disparagement onto themselves. It is also possible that the group will defend itself by trying to convince itself that the voluntary ignorance of its members does not exist because the agents possess what enables them to seek specific positive recognition (Hoggart, 1970). The agents could perhaps carry out valuable performances in another social environment and that could generate ideals of resistance (counter-culture) against dominant models (Brennan and Pettit, 2004: 225).

Lastly, these agents may resort to what Brennan and Pettit call the strategy of the "enfant terrible" (Brennan and Pettit, ibid, 189; see also Feldman, 2002) which consists of trying to draw attention to themselves by means of atypical behaviour. While this can, temporarily, bring low esteem to the agents, once esteem-services are obtained and once esteem is distributed for their qualities or performances, this will make up for the low esteem they incurred at the beginning. It is clear that this strategy of the "enfant terrible" agrees perfectly with the thesis of the "virtual" request for esteem upheld by Brennan and Pettit (4th property) insofar as they seek to draw attention through transgressive behaviours, which is not the same as explicitly requesting the value of their capacities to be considered. Transgressive behaviours do not always allow us to see a definite goal. Identifying the stakes involved in transgressive behaviour involves a process of interpretation which frequently includes a margin of uncertainty. This relative indeterminacy can force agents to face an open request for esteem. These various types of reactions can reflect relationships of domination, owing to the fact that access to one's esteem (even the increase in the capital of esteem for the most important social positions) generates direct or indirect effects of invisibility for others.

One could, however, charge against Brennan and Pettit that the "enfant terrible" behaviour gives rise to two difficulties. The first difficulty rests on the fact that the strategy of the "enfant terrible" does not assure real effectiveness. There is no guarantee that the seekers can draw or force the attention of the distributors since it does not cost them anything to retain their attitude of ignorance. In this case, it would be better to enter into a struggle for recognition which can increase the cost for distributors and thus force their attention (Voirol, 2005). But, in this case, these requests will be explicit and not virtual. Does that mean that they must inevitably fail? Brennan and Pettit's argument undoubtedly glosses over this point too quickly (second difficulty) because it misses a distinction concerning the various types of requests for recognition which appear in different contexts. In a "routine" situation where requests for recognition are formulated through capacities and performances that one seeks to make visible, an open request "exceeds" the seeker's action by becoming too insistent and therefore contradictory since it tends to make useless the only means -i.e. qualities and performances- by which esteem can be obtained. It risks, moreover, appearing as a requirement which puts the distributor's judgement under pressure, invoking the same negative results as paradoxical injunctions like "be spontaneous!", "love me!", "do not be so obedient!", etc. On the contrary, when recognition services and recognition are 
arbitrarily refused, making the request for recognition visible can appear to be the only possible option without the seeker being inevitably condemned to impotence. In this situation, it will be necessary for the seeker of recognition not to require a recognition service or recognition based on constraint, but to use it to demand a test of recognition where one will have to pay attention to the capacities and the performances which can be recognized, once the principle of effective deliberation and a public definition of the test have been accepted (Lazzeri, 2007a). In brief, struggles of recognition, considering only the cost they impose to the distributor of recognition, lead simply to the threshold where the deliberations on the nature of tests of recognition can begin. In a general way, the observation of social life reveals that requirements of recognition, expressed within the context of the workplace and within the culture of minorities or concerning questions of gender and civic claims, are closer to the strategy of the struggle for recognition than to that of the "enfant terrible". That admitted, to engage in a struggle for recognition can be understood as a "tendency" and not as a necessary process because conflicts of recognition, like other types of conflicts, have specific costs which can, in certain cases, appear to be dissuasive (Lazzeri, 2007b).

Lastly, one can maintain that what has just been said concerning recognition esteem is similarly valuable for recognition respect. The majority of the authors discussed rightly admit that a lack of recognition concerning the possibility of individual autonomy, the capacity to decide, to deliberate, to identify their own interests or to take part in social reproduction, will lead to requests for recognition, for redress or for conquest which can, as in the preceding case, be expressed by way of social conflicts.

\section{CONFLICTS OF RECOGNITION}

This kind of conflict, whether of recognition-esteem or recognition-respect, includes several properties that lead us to reject Hirschman's thesis and propose an alternative one. Initially, whatever the intensity of the conflict, conflicts of recognition include the desire for one party in the conflict to obtain positive recognition from its antagonist. By definition, it is necessary that a social relationship with the opposing agent be durably preserved (not only during the conflict, Kojève 1976: 21). The fundamental interest of those who enter into struggles of recognition is, above all, not to eliminate their opponents, but rather, to obtain a favourable and durable alteration of their own image in the mind of their opponent. ${ }^{5}$ The master and slave struggle that Hegel analyzes in the Phenomenology of Spirit is not initially and in its explicit form a fight to the death between the antagonists. Instead, it is, above all, a struggle for recognition whose destructive intention, undesired at the beginning, emerges during the struggle, when it turns out that recognition cannot occur and that each

5 We are here interested above all in the struggles for recognition (which translate the Hegelian expression Kampf um Anerkennung) rather than in the struggles of recognition (which translate the Hegelian expression Kampf des Anerkennens). In the first case, the struggle aims at obtaining a positive recognition from an agent or a social group, in the second case the struggle aims at destroying the obstacles to achieving such positive recognition. See, on this distinction, Renault, 2007. 
antagonist has become an obstacle for the other. In a struggle for recognition, to take up the description of alienation given by Sartre in Being and Nothingness (1970), one would say that the contempt $X$ experiences is equivalent to a kind of reification in Y's consciousness, in the sense that $X$ has become a prisoner of the negative image $Y$ has built, an image which he or she wants to destroy. It follows that one must add to this proposal a reciprocal conditional: in order for $X$ can get rid of his or her own negative image, he or she must first transform or abolish it in Y's mind, thereby ensuring the stability of such a result. In this way, antagonists of conflict constitute partners in long lasting social relationships, even if they are constantly in conflict (Schaap, 2004).

Secondly, this kind of conflict for recognition can obey a logic of "either/or" (the recognition either occurs or it does not), as Hirschman understands it, without this having to lead to the establishment of a relationship of domination. It would seem, instead, that the opposite is the case (see below). In any request for recognition, the one $(X)$ who requires recognition of his or her capacities or performances begins to offer a recognition-service to the other $(Y)$. This attention involves a cognitive recognition of $Y^{\prime}$ s capacity of recognition because it is impossible for $\mathrm{X}$ to ask and obtain recognition from $\mathrm{Y}$ if he or she were deprived of the capacity to dispense it. Lastly, it involves a positive and evaluative recognition of $Y^{\prime} \mathrm{s}$ capacity of recognition because, in virtue of a value transfer, $X^{\prime}$ 's capacities or performances can acquire or confirm their value only because $Y^{\prime}$ 's capacity of recognition possess value in X's eyes (Bourdieu, 1997: 284). If one refuses this transfer effect, he or she will then have to admit that $X$ is self-sufficient from the point of view of recognition. One will then have to face the problem of the tautology of his self improvement as well as the enigma of his request for recognition. Where does X's evaluation of Y's power of recognition come from? According to Sartre, it is impossible to answer this question as long as one is situated within the framework of inter-subjective relationships because, he maintains, that others "have only the right that I lend to them and that I have no other right than that which they lend to me, the unit is not recognized and falls into unjustifiable subjectivity". For Sartre, "this mutual recognition is a set of mirrors which, ultimately, rests on a lie" (Sartre, 1983: 76).

Sartre's thesis would require a long discussion, but, to get straight to the point, one can say (leaving aside emotional inter-subjective relationships of recognition in primary sociality) that the source of $Y^{\prime}$ 's recognition value lies in the density of social recognition to which (implicitly or explicitly) $X$ refers to and for which such an economy of esteem allows for $Y^{\prime}$ 's recognition value, in the eyes of $X$, comes from his or her capital of esteem, related to the connection between his or her performances and to the collective standards of esteem distribution in various possible fields. That admitted, the recognition of $Y$ by $X$ is independent of the result of $X^{\prime}$ 's request, that is, of whether its contents will or will not be satisfied, since it is inherent in the request itself. Even though $X$ may not be recognized and may nevertheless maintain his request, his recognition of $Y$ would nonetheless remain since it is inherent in that request and involves a kind of utilitarian motivation which would, as argued above (5th property of esteem), render the recognition impossible. It would only constitute a kind of self-valorization through the mediation of others. Insofar as this kind of conflict of recognition constitutes a form of social integration, it appears as 
important as that which Hirschman seeks to promote in the economic order. In this sense, one can now say that Hirschman's categorization of conflicts is invalid.

One could, however, maintain, even given Simmel's assertions in response to Hirschman's, that the difficulties with struggles for recognition will not disappear because even with the assumption that these struggles express a tendency to preserve the principle of social integration, they can nevertheless make this integration particularly expensive due to the fact that the request for recognition can supervene in a context of domination. The phenomena of distribution of recognition can fit within hierarchical relationships in which dominant agents see their social importance measured by their prestige, their standing and their esteem. These agents, around whom recognition is "solidified" and "concentrated", are transformed into authorized sources for the distribution of recognition. This status allows them to enjoy additional recognition for the capacities they are credited to possess and to enjoy deference from those who want to draw their attention in order to obtain recognition (Elias, 1974, Veyne, 1976, Pitt-Rivers, 1997, Ihl, 2004).

Let us suppose that the relationship of $X$ and $Y$ illustrates an asymmetry of status: $X$ belongs to an "involuntary association" and his or her performances are not recognized because of this membership, while $Y$ enjoys the effects of a "capital of esteem". X seeks to draw back his or her performances from social invisibility, whereas $Y$ intends only to improve the conditions of the widened reproduction of his or her capital of esteem. In this case, $X$ is not the only seeker of recognition: $Y$ also seeks recognition. But their requests for recognition are asymmetrical: the first claims simply equal treatment with regard to those whose visible performances can be compared with the standards of distribution of esteem socially admitted, the second claims superior treatment while being compared with those with whom he or she is in competition (Bourdieu, 2000) and with those who are lower than him or her in recognition. Thus, social groups made up of agents with a higher social status related to their capital of esteem must also grant recognition service to those who occupy a lower rank on the scale of esteem. Y must, in the cognitive dimension, recognize the existence of $X^{\prime}$ 's recognition, and, in the evaluative dimension, recognize the value of it.

Whether one refers to the agonistic gift theorized by Mauss (1967), or one is interested in the fight for supremacy of the symbolic capital system between economic and cultural capital in Bourdieu $(1979,1997)$, or one takes into account the recognition of conflicts within the relationships of work (Dubet, 2006; Sennett, 1998; Dejours, 1998), or one thinks of the racial domination analyzed by Margalit (1996) and the colonial one studied by Benot (1988) and Lacour de Grandmaison (2005), or one lends attention to domination in the gendered analysis of contemporary feminist theorists (Butler, 2006; Fraser 2005), or one analyzes the domination of the social and political elites (Pareto, 1968; Bourdieu, 1993; Honneth 2006), or, lastly, one considers the domination of the majoritarian cultural groups (Taylor, 1994, Walzer, 1998): in all these cases, those who dominate necessarily presuppose a capacity of recognition in those that they dominate and presuppose the value of this recognition. Without such a presupposition, any attempt at symbolic domination would appear contradictory and would vanish because the satisfaction expected by those who dominate can emerge only from the presupposition of the recognition of their superiority by the dominated. The 
Hegelian slave can be treated by his master like a slave and an instrument of work, but he or she cannot be a thing since the master's superiority rests in the fact that the slave understands that he or she is treated like a thing (Sartre, 1983: 341).

Moreover, a negative self-perception on behalf of the dominated is not enough for those who dominate if it is not simultaneously accompanied by the recognition of their superiority, which is sufficiently credible so that it satisfies them. It would seem that antagonists caught in this crossing requirement of recognition could express, despite the asymmetry of their positions, a relationship of mutual recognition: they recognize each other and have at least an equal capacity to recognize. Nevertheless, as Veyne (1976: 488, 701) and Elster (1990: 67-68) maintain, and Kojève suggested before them (1976: 25), within a relationship of domination, recognition is necessarily a contradictory phenomenon. Veyne explains that ancient Greek and Roman emperors had a desire "to reign also in the consciousness" of their subjects and thus had "the desire for the desire of the others" (ibid.). However, insofar as the emperor exerts absolute power over his subjects, a capacity which exists only in the situation of constant abuse, the emperor must face the contradiction according to which the constitutive depreciation of the subjects he rules over undermines the value of the recognition he expects from them. To put this in Elster's words, "what value can one attach to the recognition (Anerkennung) from somebody whom one does not recognize oneself? By not recognizing the other, one does not only devaluate his person, but also the recognition which he can offer by what one could call an effect of contamination" (Elster, 1990: 68). This contradiction is equivalent to that of a state which would seek the diplomatic recognition of one of its own colonies. More precisely, one confronts a destroying asymmetry between those who dominate and those who are dominated, since it is not contradictory for the latter to recognize the value in the former, as attested to by their superiority, and of whom they expect recognition in return. However, it is contradictory for the former to seek to be recognized by those to whom they deny value. The "reciprocity" of recognition is thus understood to be nothing other than a superficial and purely formal phenomenon covering a contradiction between the condition of recognition (the recognition by $\mathrm{X}$ must have a value) and the origin of its value (the recognition by $X$ does not have any value). This contradiction does not affect only Y. Its second premise also affects $X$ : it explains his or her invisibility, i.e. his or her difficulty in obtaining the recognition he or she seeks.

This analysis must, however, incorporate an additional factor concerning the asymmetrical requests for recognition. To use an expression coined by Veyne, one can say that what characterizes modern societies is strong social differentiation, it is the existence of a plurality "of scales of esteem" (1976: 113), i.e. there is a plurality of social practices which possess specific standards concerning the distribution of esteem. However, one can observe today that, in free market democracies, the economic sphere tends to impose not only its standards of organization on the whole of the social body, but also its standards of performance which affect the conditions of the distribution of esteem. Undoubtedly, one can dissociate social recognition from economic position: it is perfectly possible, in the abstract, to enjoy wealth without having prestige or social honour, just like it is possible to enjoy prestige without enjoying wealth. In the first case, one is dealing with economic capacities depreciated in socially and culturally specific contexts. In the second case, one is 
dealing with the exercise of moral, intellectual and artistic competences, the value of which, according to cultural context, is largely independent of the social conditions defined by wealth. However, considered from a general point of view, the social hierarchies prevailing in modern and contemporary societies have brought together wealth, power and prestige, whether power conferred wealth or wealth conferred power, because one found there the material for the socially valued exercise of competences (Paugam, 1991: 16-17, Fraser and Honneth, 2003: 141, 148, 252-253). Hence, it is understandable that dominant groups, promoting a higher value of their own performances and adopting a strategy of publicity, will not pay attention to performances and standards of other social groups which remain invisible. They can even continue to display disparaging attitudes toward performances considered to be lower than theirs. Moreover, it is possible that their power and influence have been exerted in the development of the criteria which determines public policies as well as the public speeches of rulers concerning the classification of the social value of performances. It is no longer a question, in this case, of simple indifference, but rather, of real social contempt. In this way, the modes of representation that other social groups form for themselves are affected by the refusal of recognition, as are their practices which follow. In fact, not only the members of involuntary associations, but also the members of voluntary associations, are concerned with this refusal of recognition. The problem of the former is that their good performances are not visible because of their depreciated status, while the problem of the second is that, whatever their status, their performances tend to become invisible or depreciated.

It is now possible to define a whole range of possibilities within the conflict between seekers and distributors of recognition, from conflicts which lead directly to satisfaction to those that lead to the deliberative organization of tests of recognition. One must obviously include, within these possibilities, the fact that recognition does not take place. However, as shown above, even if $\mathrm{X}$ is not recognized, as long as he or she maintains his or her request, the recognition of $Y$ will not cease since it is inherent in the request. On the other hand, if the recognition required by $\mathrm{X}$ seems structurally unable to occur, it will change from a struggle for recognition into a struggle of recognition, thus transforming the distributors of recognition into obstacles standing in the way of X's obtainment of recognition, likely leading to a radical conflict between them.

If this is the case, we can say that one started with a detrimental social relationship which has generated a conflict of recognition, creating a situation in which social integration is preserved but appears costly because it fits within the phenomenon of domination. Volens nolens, one would then go back to something more similar to Hirschman's thesis. Under these conditions, the following question could arise: how do we avoid the phenomena of domination within the framework of the recognition relationship? Can it exist as a kind of recognition without domination even when they are unequal, or, more exactly, could this inequality of recognition be maintained within acceptable limits? If one turns again to Brennan and Pettit's project, one could say that, just as the economy (through political economy) tries to lead to the construction of public policies, so does the project of an economy of esteem because institutions and governments can (through their political behaviour) destroy, disturb or improve the distribution of esteem. 


\section{PUBLIC POLICIES OF ESTEEM?}

One can present three prescriptive aspects of the economy of esteem for the problem we are dealing with, i.e. the visibility of performances and capacities, which constitutes a subset of the concept of publicity. The first aspect is related to the selection of the performances, the second is related to their presentation, and the third concerns their "release".

In order to analyze the first aspect of these public policies, we must note (third property) that, with regards to esteem, the attention of observers is a scarce resource and when it is focused on an aspect of a particular performance, or on a particular kind of performance, it tends to ignore other performances. Thus, attention creates alternatives in the distribution. This can easily be observed when one deals with good performances (the best) or bad ones (the worst). If the public policy in question consists of focusing attention on the best performances, there will be no incentive to become the best: only those who can reasonably be among the best undergo the pressure of the incentive of esteem while the others are excluded. If this policy concentrates on the worse performances, it will produce only the incentive to avoid being the last, but no incentive to improve performances (Brennan and Pettit, 2004: 154). The publicity effect will especially be felt at the extremes: by those whose performances are the best and the worst.

However, one must take into account the fact that, on the side of esteem, those who wish more are those who have less, because the more esteem increases, the more its marginal utility decreases, making esteem less required. So, to place the emphasis on the best performances, on those that have risen above the level of the standards of evaluation, will have an incentive effect on the average and low performances. If one adopts the strategy of the "dunce cap" by condemning the worse performances, agents will be more encouraged to avoid stigmatization than to obtain esteem. This will then lead to a reduction in the standards and thus to a decrease in the incentive to better the performance (Brennan and Pettit, 2004: 157). One may conclude that what public policies seek to ensure, in a general way, are good performances. But, this does not mean that these policies initially seek to satisfy the well-being of the best performers. Simply, one cannot disregard this last dimension, but concentrating only on the best performances increases only the wellbeing of those who tend to improve them, whereas concentrating on the reverse merely increases the suffering of the worst performers. Secondly, it is probable that observers will prefer to observe good performances than bad ones. Hence, one will be able to have more observers congregated around good performances than around bad ones, even if one may feel delight, due to envy, by observing bad performances. This strategy applies to multiple kinds of performances and, thus, applies, among other things, to the best performances in all kinds of practices and should produce an incentive for their improvement, whatever the social status of the agents.

The second aspect of these policies is understood in connection with the fact that individuals and social groups seek to obtain publicity for their performances, tend to exaggerate their own merits and tend to minimize competitors' merits. Thus, it becomes nearly impossible to choose among them and to really measure the value of their 
performances. An adequate institutional intervention would require a public evaluation of all performances, multiplying the practices of audit and independent information (ibid, 311) about organizations and institutions which would make visible the performances in competition and thus render acceptable the differences in enjoying esteem insofar as esteem-services would be impersonal.

The third and last aspect is related to the possibility of relaxing the influence of solidified beliefs, in particular, those concerning contempt. Dominant beliefs tend to generate themselves (see above) and tend to be immunized against all the forms of denial, thus prohibiting information on agents' good performances to become recognized through an esteem-service and a collective evaluation. The only possible strategy here, according to Brennan and Pettit, would consist of preventing a logic of aggregation of beliefs to emerge by institutionally favouring a change in the perception of the stigmatized social group (ibid, 315), but without proposing suitable devices.

To get straight to the point, one can acknowledge that the public policies of esteem maintained by Brennan and Pettit are interesting in their institutional regulation of the logic of the distribution of esteem regarding asymmetrical requests for recognition. This regulation is carried out primarily by means of working on the information relating to the status of the social groups and to the nature of their performances. Thus, it does not intend to leave to the most powerful agents a monopoly on information concerning their own performances, just as it does not intend to leave to them the satisfaction of a "guaranteed income of esteem" by leaving depreciated social groups locked in spirals of failure, coupled with radical conflicts. This attempt, however, presents two limitations, both of which are related to the fact that public policies of esteem are reduced to policies of information and are not oriented towards plans for transformation.

Initially, one could maintain that, in a general way, competitors in search of esteem do not confine themselves to competition simply to know how to exceed a standard in a given field. There exists, in fact, competition related to the question of knowing which performances can become socially dominant, so that the distribution of esteem does not take place when a performance surpasses a particular standard, but rather, when it conforms to socially dominant values for that type of performance in that particular field. Hence, there is competition between fields of action, between kinds of performances and between standards promoted by various social groups. This is combined with the fact that dominant groups try to promote higher value for their specific performances by adopting a strategy of justified publicity, as can be seen (see above) with regards to economics. Such a strategy of monopolization regarding the distribution of esteem tends to produce negative effects on social groups whose varied practices are socially less visible. However, it cannot readily be seen why agents, who are all in search of esteem, would exclude from their preferences a system of pluralism which recognizes different kinds of performances and, therefore, necessitates different scales of esteem, increasing the possibility of making them visible. For this to be feasible, it would need to be included in the social norms, publicly approved and supported by public policies, thereby constituting an act of social transformation. 
In the second place, public policies' emphasis on the best performances undoubtedly seeks to draw all social performances towards their best, but that provides little incentive for the improvement of performances which do not reach visibility. In other words, it is initially necessary that these performances, when they exist, be subjected to publicity. However, the attention that can initially be lent to them is dependent upon the disintegration of negative beliefs about discriminated or stigmatized groups. Still, it is precisely on this point that Brennan and Pettit's public policies of esteem appear to be silent, since they do not offer any means for untangling this aggregation of beliefs. Perhaps one can see a limit here to institutional interventions in the economy of esteem. But, perhaps, it is necessary to begin by reversing the terms of the problem. Initially, one should not unilaterally focus on the direct informational effects of the policies of esteem, but rather ask oneself whether it is not up to conflicts for recognition, i.e. conflicts which are stimulated through the indirect support drawn from policies of esteem, to transform these negative representations. Since they would endeavour to preserve the pluralism of the scales of esteem and to contribute to the visibility of performances, struggles for recognition would remain directed towards a logic of social integration, much like what Machiavelli says regarding the conflicts over political freedom. If one manages to provide a social and political framework for the struggles for recognition which avoids their most radical forms, one can then consider them a dynamic component of the construction of social relationships rather than a kind of irrational residue of the failure of cooperation which must be reduced by any means necessary.

\section{REFERENCES}

Vincent de Gaulejac, Nicole A. 1991. Le coût de l'excellence. Paris: Le Seuil.

Benot, Yves. 1988. La révolution française et la fin des colonies. Paris: La Découverte.

Bourdieu, Pierre. 1979. La distinction. Critique sociale du jugement. Paris: Minuit. 1993. La noblesse d'Etat. Paris: Minuit. 1997. Méditations pascaliennes. Paris: Le Seuil. 2000. "Le sens de l'honneur". In Esquisse d'une théorie de la pratique, précéder de trois études d'ethnologie kabyle. Paris: Le Seuil.

Butler, Judith. 2006. Défaire le genre. Paris: Editions Amsterdam.

Caillé, Alain et Christian Lazzeri. 2004. "La reconnaissance aujourd'hui. Enjeux du concept". Reoue du Mauss, $\mathrm{n}^{\circ} 23$.

Coser, L. 1982. Les fonctions du conflit social. Paris: PUF.

Cowen, T. 2005. "Review Essay: The Economy of Esteem". Politics, Philosophy \& Economics 10(4) : 3.

Dejours, Ch. 1998. Souffrance en France. La banalisation de l'injustice sociale. Paris: Le Seuil.

Dryzek, J. 2000. Deliberative Democracy and Beyond: Liberal, Critics, Contestations. Cambridge: Oxford University Press.

Dubet, F. 2006. Injustices. L'expérience des inégalités au travail. Paris: Le Seuil.

Elias, N. 1974. La société de cour. Paris: Calmann-Lévy.

Elster, J. 1986. Le laboureur et ses enfants. Deux essais sur les limites de la rationalité. Paris: Minuit. 1983. Sour Grapes. Cambridge: Cambridge University Press.

Feldman, L. 2002 "Redistribution, Recognition and the State. The Irreducibly Political Dimension of Injustice". Political Theory 30(3).

Fraser, Nancy. 2005. Qu'est-ce que la justice sociale?Reconnaissance et redistribution. Paris: La Découverte. 
Fraser, Nancy and Axel Honneth. 2003. Recognition or Redistribution. A Philosophical Exchange. Paris: Verso.

Goffman, Erving. 1974. Les rites d'interaction sociale. Paris: Minuit. 2002. L'arrangement des sexes. Paris: La Dispute.

Gutmann, Amy and D. Thomson. 1995. "Moral Disagreement in a Democracy". Social Philosophy and Policy Foundation 12(1). 1996. Democracy and Disagreement. Cambridge: Harvard University Press.

Habermas, Jürgen. 1986. Morale et communication. Paris: Cerf.

Hirschman, O. 1981. Les passions et les intérêts. Une apologie du capitalisme avant son triomphe. Paris: PUF. 1984. L'économie comme science morale et politique. Paris: Gallimard, Le Seuil.

1995. "Des conflits sociaux comme piliers de la société démocratique de marché". In Un certain penchant à l'auto subversion. Paris: Fayard.

Hoggart, R. 1970. La culture du pauvre. Paris: Minuit.

Honneth, Axel. 2000. La lutte pour la reconnaissance. Paris: Cerf.

2003. "La reconnaissance: une piste pour la théorie sociale contemporaine". In Identités et démocraties, diversité culturelle et mondialisation: repenser la démocratie, edited by $\mathrm{R}$. Le Coadic, ed. Rennes: Presses universitaires de Rennes.

2006 La société du mépris. Vers une nouvelle théorie critique. Paris: La Découverte. 2007. La réification. Petit traité de théorie critique. Paris: Gallimard.

Ihl, O. 2004. Gouverner par les honneurs. Distinctions honorifiques et économie politique dans l'Europe au début du XIXe siècle. In Genèse. Sciences sociales et histories. ${ }^{\circ} 55$.

Keshen, R. 1996. Reasonable Self-esteem. Montreal: McGill Queen University Press.

Kojève, A. 1976. Introduction à la lecture de Hegel. Paris: Gallimard.

La Cour Grandmaison, O. 2005. Coloniser, exterminer. Sur la guerre et l'État colonial. Paris: Fayard.

Lazzeri, Christian. 1999. "Peut-on composer les intérêts? Un problème éthique et politique dans la pensée du XVIIe siècle". In Politiques de l'intérêt, edited by Ch. Lazzeri et D. Reynié, eds. Presses Universitaires de Franche-Comté.

Lazzeri, Christian. 2007a. "Qu'est-ce que la lutte pour la reconnaissance?". In Conflits et confiance, edited by R. Damien and Ch. Lazzeri, eds. Presses Universitaires de Franche-Comté. 2007b. "Le prix de la lutte pour la reconnaissance". forthcoming.

.2007c. "Reconnaissance spinoziste et sociologie critique". In Spinoza et les sciences sociales, edited by F. Lordon and Y.Citton eds. Paris: Editions Amsterdam.

Levy, D.M. 1988. "The Market for Fame and Fortune". History of Political Economy. 20.

Margalit, A. 1996. La société décente. Paris: Climats.

Mauss, Marcel. 1967. Sociologie et anthropologie. Paris: PUF.

Mead, G.H. 2006. L'esprit, le soi, la société. Paris: PUF.

Pareto, V. 1968. Traité de sociologie générale. Droz.

Pettit, Philipp. 1997. "Freedom with Honor: A Republican Ideal”. Social Research 64(1). 2001. A Theory of Freedom. From the Psychology to the Politics of Agency. Polity press. 2004. Républicanisme. Une théorie de la liberté et du gouvernement. Paris: Gallimard

Pitt Rivers, J. 1997. Anthropologie de l'honneur. Paris: Hachette.

Rawls, John. 1986. Théorie de la justice. Paris: Le Seuil.

Renault, Emmanuel. 2007. "Assumer l'héritage de la théorie critique: sauver Marx par la reconnaissance?". In La reconnaissance aujourd'hui, edited by A. Caillé and Ch. Lazzeri. CNRS.

Ricoeur, Paul. 2004. Parcours de la reconnaissance. Paris: Stock.

Sartre, Jean-Paul. 1970. L'être et le néant. Essai d'ontologie phénoménologique. Paris: Gallimard. 1983. Cahiers pour une morale. Paris: Gallimard.

Schaap, A. 2004. "Political Reconciliation through a Struggle for Recognition?". Social \& Legal Studies $13(4)$.

Sen, A. 2000. Repenser l'inégalité. Paris: Le Seuil.

Sennett, R. 1998. Le travail sans qualités. Les conséquences humaines de la flexibilité. Paris: Albin Michel.

Simmel, Georg. 1992. Le conflit. Paris: Circé. 
Smith, Adam. 1999. Théorie des sentiments moraux. Paris: PUF.

Spelman, E. 1988. Inessential Women. Boston.

Taylor, Charles. 1994. Multiculturalisme et démocratie. Paris: Aubier Flammarion.

Tyler, C. 2000. What Price Fame? Cambridge: Harvard University Press.

Veyne, P. 1976. Le pain et le cirque. Paris: Le Seuil.

Voirol, O. 2005. "Les luttes pour la visibilité. Esquisse d'une pratique". Réseaux n 129-130.

Walzer, Martin. 1997. Sphères de justice. Une défense du pluralisme et de l'égalité. Paris: Seuil.

Walzer, Martin. 1998. Traité sur la tolérance. Paris: Gallimard.

Christian Lazzeri es profesor titular en la facultad de filosofía de la Universidad de Paris $X$ Nanterre, donde enseña filosofía moral y política. Con Alain Caillé, dirige el equipo de investigación (sociológica y filosófica) SOPHIAPOL sobre teorías del reconocimiento. Ha publicado sobre el tema del reconocimiento, entre otros trabajos, Conflit et confiance (con R. Damien), Presses universitaires de Franche-Comté, 2006; La reconnaissance aujourd'hui (con Alain Caillé), Ed. CNRS (a publicarse en 2008); "Le problème de la reconnaissance dans le libéralisme déontologique de John Rawls", en Revue du MAUSS, $\mathrm{N}^{\circ} 23$, 2004; "Les enjeux contemporains du concept de reconnaissance", en Revue $d u$ MAUSS, $\mathrm{N}^{\circ}$ 23, 2004; "Reconnaissance spinoziste et sociologie critique", en Spinoza et les sciences sociales (a publicarse en 2008). 